ROCZNIKI FILOZOFICZNE

Tom LXVIII, numer $4-2020$

DOI: https://doi.org/10.18290/rf20684-1

MAREK SŁOMKA

\& KAZIMIERZ WOLSZA

\title{
EVOLUTIONISM-CREATIONISM: AN INTRODUCTION TO A STILL OPEN DEBATE
}

The thesis about the unavoidable conflict between scientific, philosophical, and theological interpretations of phenomena stems from an epistemological standpoint, according to which there is only one legitimate domain of knowledge in which all phenomena can be fully and satisfactorily explained. Various forms of such epistemological monism can be found in the nineteenth-century positivism, mechanistic reductionism, dialectical materialism, and logical positivism. The followers of Auguste Comte and Friedrich Engels sought interpretations of "the-only-correct" type, or, in other words, those interpretations which would provide definitive explanations based on the cognitive perspective of just one single discipline.

In opposition to the above-mentioned view, epistemological pluralism ascribes value to a variety of domains of cognition, their respective methods, and conceptual apparatuses. The interpretations of the phenomenon of life made in biophysics, biology, philosophy, and theology are not equivalent. An attempt to discredit the cognitive value of one of these disciplines would be tantamount to a disregard for a discipline's legacy and autonomy. The recognition of epistemological pluralism is also a necessary condition for creative dialogue between the natural sciences, philosophy, and theology.

The project is funded by the Minister of Science and Higher Education under the program "Regional Initiative of Excellence" 2019-2022; project no. 028/RID/2018/19; the amount of funding: $11,742,500$ PLN.

Marek SŁomka, PhD, Habil., Assistant Professor in the Department of Philosophy of Religion, Institute of Philosophy of the John Paul II Catholic University of Lublin; address for correspondence: Wydział Filozofii, Al. Racławickie 14, 20-950 Lublin, Poland; email: mslomka@kul.pl; ORCID: https://orcid.org/0000-0001-5951-6587.

Kazimierz Wolsza, Prof. Dr. Habil., Coordinator of the Research and Didactic Team for Systematic Philosophy and History of Philosophy, University of Opole; address for correspondence: Wydział Teologiczny UO, ul. Drzymały 1a, 45-342 Opole, Poland; email: kwolsza@uni.opole.pl; ORCID: https://orcid.org/0000-0001-5352-9678. 
Cognitive pluralism was the axis of mainstream science as practiced in the British Isles in the nineteenth century. Accordingly, many naturalists tried to join the use of the inductionist methodology of William Whewell and John Herschel with taking metaphysical questions. They concerned, for example, the possibility of treating God as a factor which explains, in a noncontradictory manner, the existence of the laws of nature. ${ }^{1}$ A similar approach was characteristic of those researchers interested in animate world who, after the profound transformations that took place in the second half of the nineteenth century, saw the possibility of a complementary coexistence of the scientific, philosophical, and theological versions of evolutionism.

At the end of the nineteenth century, many Christian thinkers recognized the value of interdisciplinary dialogue. They saw the opportunity offered by the development of the natural sciences to deepen their reflection on the relationship between the Creator and creation. James Iverach understood the work of creation as the continuous action of God, whose power is not manifested in exceptional situations only but sustains everything in existence. In referring to the idea of creatio continua, the Scottish priest wrote:

To me creation is continuous. To me everything is as it is through the continuous power of God; every law, every being, every relation of being are determined by Him, and $\mathrm{He}$ is the Power by which all things exist. I believe in the immanence of God in the world, and I do not believe that He comes forth merely at a crisis. ${ }^{2}$

The departure from interventionist interpretations of the Creator's influence on creation provided space for explanations that allow one to understand evolution as a rational process of the continuation of the divine work of creation.

Iverach clearly stressed the epistemological differences between the natural sciences and the humanities. These two fields of reflection are concerned with different aspects in their research, and, as a result, the worldviews presented by these fields are different. In order to retain his cognitive competence and to closely follow the language of his discipline, the scientist should not refer to the hypothesis of God guiding the develop-

\footnotetext{
${ }^{1}$ Józef ŻyCIŃSKI, God and Evolution: Fundamental Questions of Christian Evolutionism, trans. Kenneth W. Kemp and Zuzanna Maślanka (Washington, DC: Catholic University of America Press, 2006), 11-19.

2 James Iverach, Christianity and Evolution (London: Hodder \& Stoughton, 1894), 175-76, accessed December 10, 2019, https://archive.org/details/christianityevol00iver/page/174; IVERACH, Theism in the Light of Present Science and Philosophy (London: Hodder \& Stoughton, 1899).
} 
ment of nature. However, where the biologist limits himself to analyzing the interactions of laws and chance, the theologian seeks deeper justifications in interpreting evolutionary processes in terms of God's creative action. The theological explanation of how the world functions does not leave us convinced that it is ruled by a "blind fate," traces of the Logos in the laws of nature, whose origins, character, and meaning cannot be fully understood within the framework of the natural sciences. Moreover, the philosophical and theological interpretation of the process of evolution touches upon the problem of the rationality of this process, as well as the emergence of increasingly complex structures which, at some stage, take the form of life and consciousness. With such an approach, emphasis on the "tyranny of chance" in the functioning of nature must give way to a reflection which underscores that, as a result of natural processes, man appears on the stage of history as the most developed species, referred to in Christian thought as the "crown of creation."

Iverach understood that the introduction of subtle meta-scientific distinctions makes it possible to see the process of cognizing the world and man as a complementary integration of partial truths, as relativized to the cognitive perspective of a given discipline. In order to prevent conflicts between religion and science, he also postulated the development of a biblical hermeneutics that would allow for a proper interpretation of the texts of Scripture, with respect to both the Christian vision of reality and the contemporary understanding of nature. These postulates gained additional value from the perspective of the emerging American anti-scientific fundamentalism that treated the biblical descriptions of creation as a statement relative to natural history.

Since the second half of the nineteenth century, a deep reevaluation of the evolutionary concept of nature has taken place. After Charles Darwin published The Origin of Species, the theory of natural selection appeared to be a hypothetical alternative to the Aristotelian idea of species invariability. Over the years, this theory has gained an increasing degree of empirical confirmation in such scientific fields as paleontology, comparative anatomy, biogeography, embryology, and biochemistry. Many Christian intellectuals have noted this transformation. While anti-evolutionary sentiment was growing in conservative American Protestant circles, the German Lutheran theologian, Werner Elert (1885-1954), wrote in his monumental work Kampf um

\footnotetext{
${ }^{3}$ Cf. Józef ŻyCiŃsKi, "Naturalistyczne a chrześcijańskie interpretacje ewolucji,” Forum Teologiczne 9 (2008): 47.

${ }^{4} \mathrm{Cf}$. Iverach, Christianity and Evolution, $128 \mathrm{ff}$.
} 
das Christentum (1921) that the theory of evolution is as legitimate a theory concerning the natural world as the atomic theory or the theory of light. Elert emphasized that, instead of judging or attempting to prove the theory of evolution wrong, theologians aware of their competence should rather convincingly demonstrate the essence of their own doctrines. ${ }^{5}$

Today, broadly understood evolutionism is treated as a meta-scientific paradigm. Positions denying the existence of evolutionary processes are considered to be manifestations of para-scientific, or even pseudo-scientific activity that ignores not only the achievements of great naturalists but also the methodological principles and epistemological distinctions recognized in the canon of contemporary natural sciences. However, the fundamental change of the scientific status of evolutionism did not eliminate the controversies connected with it. This is due, inter alia, to the fact that the dynamic development of empirical sciences based on evolutionary models has forced the reconsideration of such important issues as the place of man in nature, his relationship with other species, and the conditions for reconciling the scientific and theological versions of human prehistory.

Any possibility of interdisciplinary dialogue (not only in terms of anthropology) is rejected by such thinkers as Richard Dawkins, Daniel Dennett, Sam Harris, and Victor J. Stenger. In many publications they use the theory of evolution to promote scientism and discredit religion. Dennett claims that the theory of evolution is incompatible with religious belief. In his work, Darwin's Dangerous Idea, he steps beyond his scientific competence and puts forward the thesis that neither the final nor causal act of the Creator has influenced the formation of species, including homo sapiens. ${ }^{6}$

However, there are also theists who emphasize that evolutionism, due to its materialistic implications, is incompatible with Christian doctrine. In this intellectual environment, the Darwinian legacy is portrayed as a threat to Christian anthropology. In 1998, a book by George Sim Johnston titled Did Darwin Get It Right? Catholics and the Theory of Evolution was published in the United States. ${ }^{7}$ The year of 2005 marked the appearance of its Polish translation as part of the Faith and Science series by WAM Publishing

\footnotetext{
${ }^{5}$ Werner Elert, Der Kampf um das Christentum. Geschichte der Beziehungenzwischen dem evangelischen Christentum in Deutschland und dem allgemeinen Denkenseit Schleiermacher und Hegel, 2nd ed. (Hildesheim: Georg Olms, 2005), 234.

${ }^{6}$ Cf. Daniel C. Dennett, Darwin's Dangerous Idea: Evolution and the Meanings of Life (New York: Simon \& Schuster, 1995), 310.

${ }^{7}$ George S. Johnston, Did Darwin Get It Right? Catholics and the Theory of Evolution (Huntington, IN: Our Sunday Visitor Publishing Division, 1998).
} 
House. Books previously published in this series by authors such as Édouard Boné and George Coyne were promising signs of fostering dialogue between theology and the natural sciences.

In his work, Johnston presents projections for which there is hardly any rational justification. In his opinion, there is a high probability that Darwin will soon share the fate of Marx and Freud, joining the group of forgotten ideologists. In suggesting the importance of empirical evidence against Darwinism, Johnston states that abandoning Darwinism will open the way for traditional metaphysics. This publication encourages everyone to put The Origin of Species back on the shelf and open the works of Aristotle and Thomas Aquinas. Johnston writes: "Modern man will no longer be obliged to view himself as a shifting, accidental thing with no more dignity than a stone or jellyfish. Biology will be freed from the straitjacket of mechanistic philosophy and, more importantly, the doctrine of creation, whose eclipse in recent generations has had a devastating effect on Christian apologetics, will be restored to its rightful place." 8

In the context of these statements, it should be stressed that there are no substantive reasons to combine biological evolutionism with mechanicism. However, even more important is the problem of man's place in nature. The theory of evolution is supposed to show our species as degraded to the level of being simple living organisms or even physical objects. As a way of restoring man's proper status, it is proposed to reject the results of modern science and replace them with classical metaphysical reflection. Such proposals must be assessed unequivocally in the negative, as they do not represent a thorough presentation of the foundations of the biological theory of evolution.

Johnston's publication contains many radical theses. In his opinion, "[it is] scarcely possible to exaggerate the subsequent influence of Darwin's theory on Marxist though and therefore on the crimes committed, and still to be committed, by Marxist regimes." 9 The reader will then find there a statement concerning the negative impact of Darwin on capitalism, and, finally, a suggestion regarding the influence of evolutionism on the development of National Socialism. Although Johnston stresses that perceiving evolutionary theory as the cause of the outbreak of World War II is a simplification, ${ }^{10}$ he also states that there is only "a short step from Darwin to the gas chambers and abortion mills.",11

\footnotetext{
${ }^{8}$ Ibid., 12.

${ }^{9}$ Ibid., 100.

${ }^{10}$ Ibid., 101.

${ }^{11}$ Ibid., 103. It is worth noting the considerable impact of Johnston's publications, as he writes
} 
Equally irrational statements can be found in a number of texts that have been influenced by such publications as Henry M. Morris's Troubled Waters of Evolution ${ }^{12}$ and J. W. G. [or: Wallace] Johnson's The Crumbling Theory of Evolution. ${ }^{13}$ These publications are often referred to by Polish creationists. Known for their public activity, Maciej Giertych and Mieczysław Pajewski claim that evolutionism threatens Christian doctrine and undermines the foundations of religion also in the social dimension. ${ }^{14}$ Such theses are also put forward in some Polish publications produced in ecclesiastical and theological circles. ${ }^{15}$

Bernard Hałaczek emphasized that in the history of mutual relations between theology and the theory of evolution three main models of mutual relation can be seen: opposition, tolerance, and affirmation. ${ }^{16}$ These intellectual attitudes coexist even today in the discussion between creationists and evolutionists, which, despite the passing of time, has a clear set of dynamics and multiplicity of determinants. Grzegorz Bugajak (1966-2020) writes about this in his paper contained in this issue of the Annals of Philosophy: "It would seem that today, more than 150 years after the formulation of the theory of evolution as presented by Charles Darwin, all possible positions in the evolutionism-creationism debate have long been formulated and discussed. However, for some reason the debate on this problem continues to be revived. In particular, many authors who declare their attachment to Christian thought are dissatisfied with the excessive (in their opinion) concessions made by other representatives of this tradition to evolutionism" ("Czy pro-

in many American journals, including Catholic ones. He is a contributing editor for the Crisis magazine and the National Catholic Register. His articles and essays have appeared in Harpers, The American Spectator, Commentary, The Wall Street Journal, Harvard Business Review, Envoy, and Catholic World Report. He is a recipient of the Journalism Award from the Catholic Press Association. For the sake of fairness, however, it should be added that the book by Johnston quoted in this text has received critical reviews in the U.S., e.g., in Reports of the National Center for Science Education (vol. 19, no. 6 [December 2, 2008], https://ncse.ngo/review-did-darwinget-it-right).

${ }^{12}$ Henry M. Morris, Troubled Waters of Evolution (San Diego, CA: Creation-Life Publishers, 1974).

${ }^{13}$ J. W. G. Johnson, The Crumbling Theory of Evolution (Brisbane: Queensland Binding Service, 1982). The book was published in the US as Evolution? and in Poland as Na bezdrozach teorii ewolucji (trans. Jan Kempski [Warszawa-Struga: Michalineum, 1989]).

${ }^{14}$ Maciej Giertych, "Nauka na służbie ideologii," Opoka w kraju 46 (2003): 6-8; Mieczysław PAJEwSKI, "Meandry sporów o pochodzenie (cz. 5)," Idź pod prąd 3, no. 8 (August 2005): 8-9.

${ }^{15}$ This is presented in detail by Marek Słomka in his article published in this issue.

${ }^{16}$ Bernard HaŁaczeK, "The Evolution of Theological Views on Evolution," Przeglad Antropologiczny 60 (1987): 3-12. 
cesy naturalne mogą realizować cele nadnaturalne? [Can Natural Processes Realize Supernatural Goals?]").

Reflections on various aspects of the debate between evolutionism and creationism do not seem to be made any easier by the polysemy of terms. Both positions have many variations that enter into diverse mutual relations. In order to minimize possible misunderstandings, the authors of the papers contained in this issue strive for terminological precision through, inter alia, the use of modifiers, which allow one to distinguish between biblical, dogmatic, scientific, metaphysical, anti-evolutionary, and other forms of creationism. The term "creationism" itself has nowadays been largely appropriated by anti-evolutionary trends. Today, unfortunately, the first association with creationism is not the idea of creation (creatio), but the negation of evolution.

The position that integrates the Christian teaching concerning the creation of the world and man by God with the theory of evolution is most often referred to as evolutionary theism, theistic evolutionism, or Christian evolutionism. ${ }^{17}$ Theistic evolutionism - a particular form of philosophical evolutionism, i.e., of going beyond the field of the natural sciences-is usually presented as an alternative position to anti-evolutionary creationism. It is worth emphasizing that theistic evolutionism is actually a form of creationism because it recognizes the fundamental role of God the Creator in the origin and development of nature as creatio continua. For this reason, the name "evolutionary creationism" is also present in the literature of the subject. ${ }^{18}$

Many contemporary authors try to combine the concept of creation and evolution in a variety of ways, calling evolution a creative process ${ }^{19}$ or a manifestation of the act of creation. The creativity of evolution manifests itself, for example, in the genesis of new species. The survival of some of these species depends on their adaptability, with finding unoccupied niches

${ }^{17}$ Cf. Marek SŁomкA, Ewolucjonizm chrześcijański o pochodzeniu człowieka (Lublin: Gaudium, 2004).

${ }^{18}$ Cf. Józef Marceli DoŁęGa, Kreacjonizm i ewolucjonizm. Ewolucyjny model kreacjonizmu a problem hominizacji (Warsaw: Wydawnictwo ATK, 1988), 16; Anna LemańsKA, "Status metodologiczno-epistemologiczny koncepcji inteligentnego projektu," in Pogranicza nauki. Protonauka - paranauka - pseudonauka, ed. Józef Zon (Lublin: Wydawnictwo KUL, 2009), 310-14.

${ }^{19}$ Cf. Kazimierz KŁósAK, "Zagadnienie stworzenia wszechświata w ujęciu P. Teilharda de Chardin" (Proceedings of the Scientific Conference of the Philosophical Section of Professors of Higher Theological Educational Institutions in Poland, Kraków, April 21-22, 1965), Studia Philosophiae Christianae 1, no. 2 (1965): 283. 
becoming an essential factor of survival. A special stage of evolutionary creativity is the emergence in our ancestors of the ability to think reflexively and articulate thought through verbal speech. With such unique stages of the development of the universe in mind, T. Dobzhansky calls evolution "a process that transcends itself," and "a way in which creative work is accomplished." ${ }^{20}$ Attempts to characterize this process in detail can lead to deeply differentiated philosophical proposals, some of them included in this issue of the Annals. One of the principal objectives of this issue is to present the problem of evolutionism in relation to main contemporary philosophical controversies.

Dariusz Dąbek, in his article "Evolutionism-Creationism: In Search for a Platform of Dialogue," draws attention to the issue of precisely distinguishing the theory of evolution from evolutionism. In this basic approach, the theory of evolution is presented as a rational reconstruction of the processes occurring in nature, while evolutionism is presented as a philosophical standpoint which, apart from scientific data, also adopts other theses, e.g., philosophical ones. ${ }^{21}$ This distinction, however, has not been widely accepted.

Reading all the texts contained in this issue allows us to grasp those aspects of the evolutionism-creationism question which dominate today in Polish and foreign literature. In this context, three important fields of contemporary debate are clearly outlined that differ not only in terms of their detailed subject matter, but also in their choice of arguments. The first area is the dispute between evolutionism and the theory of intelligent design, considered by some to be the next stage of an earlier dispute between evolutionism and scientific creationism (Anna Lemańska, Tadeusz Pabjan). However, this dispute is interpreted differently depending on how one understands the theory of intelligent design. According to the supporters of this concept, intelligent design is a scientific alternative to the theory of evolution. To emphasize the natural character of ID, its representatives try to avoid religious references and do not define the nature of the designer. Among the authors published in this issue, Andrzej Maryniarczyk SDB (19502020) and Michał Chaberek OP are in favor of such an understanding of the

${ }^{20}$ Cf. Theodosius Dobzhansky, The Biological Basis of Human Freedom (New York: Columbia University Press, 1956), 124; Theodosius Dobzhansky, "Creative Evolution," Diogénes 15 (1967): 62-74.

${ }^{21}$ Zygmunt Hajduk, Filozofia przyrody. Filozofia przyrodoznawstwa. Metakosmologia (Lublin: Towarzystwo Naukowe KUL, 2004), 315. 
theory of intelligent design. Critics of this approach indicate, however, that the theory of intelligent design has not only a scientific but also a philosophical or even a worldview layer which goes beyond the field of science. Analyses of the methodological and epistemological status of ID, together with a presentation of its genesis, as well as the platform on which the dispute with evolutionism takes place, can be found here in the articles of Anna Lemańska, Tadeusz Pabjan, and Dariusz Dąbek. These articles cover a wealth of literature on the subject, including Polish literature, written in four major Polish centers that stand out in the study of these issues: Warsaw, Lublin, Kraków, and Zielona Góra.

The second area where discussions inspired by evolutionism take place is the area of Thomistic metaphysics. The Thomistic philosophers, especially from the Louvain circles, have long dealt with the issue of the relation between evolutionism and creationism. They have tried to interpret the creative act and the process of evolution in metaphysical terms, indicating the possibility of cooperation between the First Cause (the Creator) and secondary causes (natural processes). In Polish philosophy after World War II, such interpretative proposals, which drew on natural sciences and Thomistic metaphysics, were included in the writings of such authors as: Kazimierz Kłósak (1911-1982), Tadeusz Wojciechowski (1917-2000), Ludwik Wciórka (19282000), and Józef Marceli Dołęga (1940-2000). However, such discussions within Thomistic metaphysics lost their dynamics and originality over time and attempts to integrate evolutionary thinking with Thomistic metaphysics were even considered a failed experiment. On the one hand, in the Thomistic milieu the difference between the scientific and metaphysical fields was emphasized, as well as the need to "purge" metaphysics of elements from the natural sciences. In his discussion on the relationship between metaphysics and modern physics, Stanisław Kamiński (1919-1986) appealed: "Let us protect metaphysics from any confusion with any kind of physics!",22 Mutatis mutandis, these words can also be applied to the relation between metaphysics and evolutionary biology. On the other hand, what Michał Heller emphasized was appreciated: Thomistic metaphysics was rooted in the Aristotelian vision of science, whereas the natural sciences were born out of the Archimedean tradition, and therefore the attempts to create a Thomistic philosophy "corresponding" to the sciences had failed. ${ }^{23}$ As a result of these

\footnotetext{
${ }^{22}$ Stanisław KAmiński, Pisma wybrane, vol. 5, Światopoglad - religia - teologia. Zagadnienia filozoficzne i metodologiczne, ed. Monika Walczak and Andrzej Bronk (Lublin: Towarzystwo Naukowe KUL, 1998), 270.

${ }^{23}$ Michał Heller, Nowa fizyka i nowa teologia, 6th ed. (Kraków: Copernicus Center Press, 2016), 98 .
} 
findings, Thomistic metaphysicians have rarely dealt with the issue of evolution, and interpreted the changes occurring in the world in terms of potency and act as well as substance and accidents. In turn, thinkers who took up the subject of evolution and the relationship between this scientific theory and Christian doctrine-whether in natural philosophy or in interdisciplinary studies - abandoned metaphysical categories as an unnecessary burden, and sought other, more effective, tools. The recent return to the discussion of the relation between the theory of evolution and Thomism in Polish circles has been inspired by the translation into Polish of a work of a group of Dominican authors, who have once again tackled the issue of the relation between creation and evolution from the Thomistic perspective. ${ }^{24}$ The intention of these authors was not only to present the key issues that emerge at the intersection of evolutionism and theism, but to interpret these issues in light of Thomistic philosophy. Discussion concerning the project of the Thomistic metaphysics of evolution has been going on for several years (the first edition of Thomistic Evolution was published in 2016). The authors of this work have established a research group and created a website (https://www.thomisticevolution.org) where they publish their texts and polemics. Their work has been discussed on the websites of the Vatican Observatory and the Templeton Foundation. Michał Chaberek, the author of one of the articles presented in this issue of the Annals, actively participates in the discussion on "Thomistic evolution," and gets involved in polemics with American authors. ${ }^{25}$ The debate has now also moved to Poland. The concept of Thomistic evolution has been favorably received by Mariusz Tabaczek OP of the Thomistic Institute, the author of the afterword to the Polish edition of Thomistic Evolution. Criticism of this position is taken up in this issue by Michał Chaberek in his "Skąd pochodzą nowe formy substancjalne? [Where Do the Substantial Forms Come From?]" and by Andrzej Maryniarczyk in "Metaphysical Creationism and the Paradoxes of Evolutionary Theism," who claim that the evolutionary theism developed within the framework of Thomistic metaphysics leads to paradoxes and is inconsistent with the writings of Thomas Aquinas. The discussion undertaken by con-

\footnotetext{
${ }^{24}$ Nicanor Pier Giorgio Austriaco et al., Thomistic Evolution: A Catholic Approach to Understanding Evolution in the Light of Faith (Tacoma: Cluny Media, 2016); published in Poland as Ewolucja w świetle wiary. Perspektywa tomistyczna, trans. Grażyna Gomola and Aleksander Gomola (Poznań: W drodze, 2019).

${ }^{25}$ Michał CHABerek, "Classical Metaphysics and Theistic Evolution: Why Are They Incompatible?” Studia Gilsoniana 8, no. 1 (2019): 47-81.
} 
temporary Thomists shows (not for the first time, though) that-on the grounds of Thomism-one can come across diverse positions and various ways of referring to the heritage of St. Thomas. There are also all types of relations between theism and evolutionism distinguished by John F. Haught: conflict, contrast, and convergence. This typology can be considered as a simplified version of Ian Barbour's well-known proposal (conflict, independence, dialogue, integration). ${ }^{26}$

The third area of discussion is theistic (Christian) evolutionism. This involves an affirmative attitude to the theory of evolution. The inclusion of the evolutionary view of nature in the theistic position causes some of the categories used so far, which grew out of a different image of the world, to be rejected and others redefined. On the one hand, theistic evolutionism must enter into discussions and polemics with traditional theism, the theory of intelligent design, and with new atheism. ${ }^{27}$ On the other hand, many concepts used so far by theistic philosophy and theology need to be clarified. In the works of the theistic evolutionists there are reflections on the concept of God as a person, His relation to the world, transcendence, and immanence, the relation of nature to the supernatural, the action of God in the world, the understanding of creation, purposefulness, causality, the interventionism of God, and the concept of miracles, among others things (articles by Grzegorz Bugajak, John F. Haught, Tadeusz Pabjan, and Marek Słomka). New distinctions emerge here, such as one between external and internal purposefulness, Special Divine Action (SDA) and General Divine Action (GDA), as well as between non-traditional theological positions such as panentheism and Christian naturalism. There are many more of these problems, developed primarily in contemporary Anglo-Saxon religious philosophy, with there being perhaps even more than $101 .^{28}$

${ }^{26}$ Ian BARBOUR, "Jak układają się stosunki między nauką a teologią," in Refleksje na rozdrożu. Wybór tekstów z pogranicza wiedzy $i$ wiary, ed. Stanisław Wszołek (Tarnów: Biblos, 2000), 29-75; Radosław TyraŁa, Dwa bieguny ewolucjonizmu. Nauka i religia $w$ poznawczym wyścigu zbrojeń (Kraków: Nomos, 2007), 13-25.

${ }^{27}$ Trrala, Dwa bieguny, 61-95; Tadeusz PabJan, Anatomia konfliktu. Między nowym ateizmem a teologia nauki (Kraków: Copernicus Center Press, 2016); Andrzej MaryNIARCZYK, Dlaczego stworzenie ,ex nihilo”. Teoria metafizycznego kreacjonizmu (Lublin: Polskie Towarzystwo Tomasza z Akwinu, 2018), 95-143; Michał CHABEREK, Święty Tomasz z Akwinu a ewolucja (Kęty: Marek Derewiecki, 2019), 188-99.

${ }^{28}$ John F. Haught, Responses to 101 Questions on God and Evolution (New York: Paulist Press, 2001); Haught, God after Darwin: A Theology of Evolution (Boulder: Westview Press, 2000). 
Philosophical and theological discussions are reflected in the media, where they are often presented in a simplified and distorted way. ${ }^{29}$ These discussions are also reflected in the way religious faith is transmitted. In Poland, it is 30 years since religious education was transferred from pastoral centers to schools. This anniversary became an opportunity for many considerations on the state of school catechization. However, little attention was given to the question of how the relationship between science and religion, including the theory of evolution and the doctrine of creation, is presented in religious classes. A study of materials used in religious education in Polish schools was conducted by Marek Słomka. The shortcomings and errors indicated there require not only correction but also reflection on their causes. Some of these causes are indicated in several texts contained in this issue: the aversion of theological circles to the natural sciences, trust in only one (e.g., Thomistic) system of concepts, a lack of understanding of the concepts used by science and meta-science (especially the concept of scientific theory), a reliance on simplified studies published in the press and on the internet, the conviction that one should not give in to alleged pressure or blackmails from science, etc.

According to the profile of the Annals of Philosophy, the issue of evolutionism-creationism addressed here is analyzed from the perspective of such disciplines as the philosophy of science, the philosophy of nature, metaphysics, and the philosophy of religion. The authors use analogies provided by the history of science to justify many of their theses. In-depth discussion of the issue is ensured by references to the latest literature concerning this subject. This introduction, as well as the articles written by Andrzej Maryniarczyk and Dariusz Dąbek are published here in English thanks to the professional efforts of Dr. Maciej Bogdan Stępień.

One of the most important aspects of the evolutionism-creationism issue is reflected in the question: Can evolution of nature be treated as a manifestation of God's design? The answer to this question depends largely on what content is associated with the term "design." It is now impossible to defend the vision, full of anthropomorphisms, which William Paley developed several decades before the works on the role of natural selection in the evolution of nature were first published. However, it does not follow that, after rejecting his naïve concept, the world must appear as a scene without any

${ }^{29}$ Cf. Kazimierz Wolsza, "Nowy spór teologii z teorią ewolucji? O niektórych aspektach debaty z lat 2005-2006," Forum Teologiczne 9 (2008): 87-100. 
plan, where the main role is played by chance as opposed to the deliberate action of God. After all, He can see something completely different in what we see as chance. He can also manifest His presence in the processes of nature and in structures much more complex than the famous watch, thus associated with the analogy promoted by the author of Natural Theology. ${ }^{30}$ Today, there is a wide range of perspectives for the development of new and ambitious evolutionary approaches, in which Christian thought is creatively combined with the latest scientific discoveries.

\section{BIBLIOGRAPHY}

Austriaco, Nicanor Pier Giorgio et al. Thomistic Evolution: A Catholic Approach to Understanding Evolution in the Light of Faith. Tacoma: Cluny Media, 2016. Published in Polish as Ewolucja w świetle wiary. Perspektywa tomistyczna. Translated by Grażyna Gomola and Aleksander Gomola. Poznań: W drodze, 2019.

BARbOUR, Ian. "Jak układają się stosunki między nauką a teologią." Translated by Stanisław Wszołek, in Refleksje na rozdrożu. Wybór tekstów z pogranicza wiedzy $i$ wiary, ed. Stanisław Wszołek, 29-75. Tarnów: Biblos, 2000.

Chaberek, Michał. "Classical Metaphysics and Theistic Evolution: Why Are They Incompatible?" Studia Gilsoniana 8, no. 1 (2019): 47-81.

Chaberek, Michał. Święty Tomasz z Akwinu a ewolucja. Kęty: Marek Derewiecki, 2019.

Dennett, Daniel C. Darwin's Dangerous Idea: Evolution and the Meanings of Life. New York: Simon \& Schuster, 1995.

Dobzhansky, Theodosius. “Creative Evolution.” Diogénes 15 (1967): 62-74.

Dobzhansky, Theodosius. The Biological Basis of Human Freedom. New York: Columbia University Press, 1956.

DoŁĘGA, Józef M. Kreacjonizm i ewolucjonizm. Ewolucyjny model kreacjonizmu a problem hominizacji. Warsaw: Wydawnictwo ATK, 1988.

Elert, Werner. Der Kampf um das Christentum. Geschichte der Beziehungenzwischen dem evangelischen Christentum in Deutschland und dem allgemeinen Denkenseit Schleiermacher und Hegel, 2nd ed. Hildesheim: Georg Olms, 2005.

Giertych, Maciej. "Nauka na służbie ideologii.” Opoka w kraju 46 (2003): 6-8.

HaJduk, Zygmunt. Filozofia przyrody. Filozofia przyrodoznawstwa. Metakosmologia. Lublin: Towarzystwo Naukowe KUL, 2004.

HaŁaczek, Bernard. "The Evolution of Theological Views on Evolution.” Przeglad Antropolog iczny 60 (1987): 3-12.

Haught, John F. God after Darwin: A Theology of Evolution. Boulder: Westview Press, 2000.

${ }^{30}$ William PALey, Natural Theology: or, Evidences of the Existence and Attributes of the Deity, Collected from the Appearances of Nature (London: R. Faulder; Philadelphia, PA: John Morgan, 1802). 
Haught, John F. Responses to 101 Questions on God and Evolution. New York: Paulist Press, 2001.

Heller, Michał. Nowa fizyka i nowa teologia, 6th ed. Kraków: Copernicus Center Press, 2016.

Iverach, James. Christianity and Evolution. London: Hodder \& Stoughton, 1894. Accessed December 10, 2019. https://archive.org/details/christianityevol00iver/page/174.

Johnson, J. W. G. The Crumbling Theory of Evolution. Brisbane: Queensland Binding Service, 1982. Published in the US as Evolution? and in Poland as Na bezdrożach teorii ewolucji. Translated by Jan Kempski. Warszawa-Struga: Michalineum, 1989.

Johnston, George S. Did Darwin Get It Right? Catholics and the Theory of Evolution. Huntington, IN: Our Sunday Visitor Publishing Division, 1998.

KAmiŃski, Stanisław. Pisma wybrane. Vol. 5, Światopogląd-religia-teologia. Zagadnienia filozoficzne i metodologiczne, ed. Monika Walczak and Andrzej Bronk. Lublin: Towarzystwo Naukowe KUL, 1998.

KŁóSAK, Kazimierz. "Zagadnienie stworzenia wszechświata w ujęciu P. Teilharda de Chardin” (Proceedings of the Scientific Conference of the Philosophical Section of Professors of Higher Theological Educational Institutions in Poland, Kraków, April 21-22, 1965). Studia Philosophiae Christianae 1, no. 2 (1965): 283.

LEMAŃSKA, Anna. "Status metodologiczno-epistemologiczny koncepcji inteligentnego projektu." In Pogranicza nauki. Protonauka - paranauka - pseudonauka, edited by Józef Zon. Lublin: Wydawnictwo KUL, 2009.

MaryniarczyK, Andrzej. Dlaczego stworzenie ,ex nihilo”. Teoria metafizycznego kreacjonizmu. Lublin: Polskie Towarzystwo Tomasza z Akwinu, 2018.

Morris, Henry M. Troubled Waters of Evolution. San Diego, CA: Creation-Life Publishers, 1974.

Pabjan, Tadeusz. Anatomia konfliktu. Między nowym ateizmem a teologia nauki. Kraków: Copernicus Center Press, 2016.

PAJewski, Mieczysław. "Meandry sporów o pochodzenie (cz. 5)." Idź pod prąd 3, no. 8 (August 2005): 8-9.

Paley, William. Natural Theology: or, Evidences of the Existence and Attributes of the Deity, Collected from the Appearances of Nature. London: R. Faulder; Philadelphia, PA: John Morgan, 1802.

SŁomKA, Marek. Ewolucjonizm chrześcijański o pochodzeniu człowieka. Lublin: Gaudium, 2004.

TyraŁa, Radosław. Dwa bieguny ewolucjonizmu. Nauka i religia w poznawczym wyścigu zbrojeń. Kraków: Nomos, 2007.

Wolsza, Kazimierz. "Nowy spór teologii z teorią ewolucji? O niektórych aspektach debaty z lat 2005-2006." Forum Teologiczne 9 (2008): 87-100.

ŻyCIŃSKI, Józef. "Naturalistyczne a chrześcijańskie interpretacje ewolucji." Forum Teologiczne 9 (2008): 47.

ŻyciŃski, Józef. God and Evolution: Fundamental Questions of Christian Evolutionism. Translated by Kenneth W. Kemp and Zuzanna Maślanka. Washington, DC: Catholic University of America Press, 2006. 